\title{
The Effectiveness of Using English as the Sole Medium of Instruction in English Classes: Student Responses and Improved English Proficiency
}

\author{
Ruth M. H. WonG \\ English Department \\ The Hong Kong Institute of Education \\ Hong Kong
}

Received: 3 June 2009 / Accepted: 16 September 2009

ISSN: $1697-7467$

\begin{abstract}
This longitudinal action research study investigates the effectiveness of English as the sole medium of instruction in Hong Kong by comparing the preferences of two non-native English language classes under two different teaching policies, while also examining both classes for any potential correlations with improved English proficiency. In one English class, an English-only policy was strictly enforced, while in the second class the use of Cantonese (the students' first language) was permitted. Results revealed that not only did the class under the strict policy have a stronger preference for English as the sole medium of instruction, but their English proficiency had also become higher than that of the more Cantonese-tolerant class.
\end{abstract}

La efectividad del uso del inglés como único medio de instrucción en las clases de inglés: respuesta de los estudiantes y mejora en los niveles

RESUMEN: Este estudio investigación-acción se centra en la efectividad del ingles como único medio de instrucción en Hong-Kong comparando las preferencias de dos grupos de lengua inglesa que no son nativos bajo dos políticas diferentes, a la vez que se examinan ambas clases para observar posibles correlaciones con respecto a una mejora en el nivel de ingles. En una de las clases de inglés, se sigue una política estricta de "sólo en ingles", mientras que en la segunda, sí se permitía el uso del cantonés (primera lengua de los estudiantes). Los resultados demuestran que el grupo sometido a la política estricta de "solo en ingles" prefería mucho más el uso de esta lengua además de que también su nivel había mejorado mucho más que el grupo en el que se permitía el cantonés.

\section{INTRODUCTION}

The medium of instruction in 'English as a Second Language' (ESL) classrooms has long been a subject of debate in Hong Kong, where there have been calls for the development of a comprehensive classroom-language policy. Is it best to have English classes conducted strictly in English? Or should English lessons allow limited use of a local language if it seems to help 
students in the short term? This paper will examine the effectiveness of a strict 'English-only' medium of instruction policy in English classes, and the policy's relationship to English proficiency gained - as well as consider insights gained from student responses on these matters.

Many studies have been conducted to examine the issue of medium of instruction, perhaps more than any other aspect of education. Broadly speaking, previous studies focused on how the expansion of the Anglo-Chinese system affected schools (Chan, 1996 \& 1997; Chan \& Tan, 2006; Ferguson, 2006; He, 2007; Johnson, 1993; Lai, 2002; Mahwah, 2004; Poon, 2000) and attempted to assess student achievements and attitudes in order to test hypotheses regarding the relative merits of the Anglo-Chinese and Chinese Middle school systems. These studies emphasised that cognitive growth and the development of intellectual processes were more important than the accumulation of information (Bruner, 1984; Smith, 1983; Vygotsky, 1962; Weaver, 1988; Wells, 1986). Some scholars indicated that second language learners were more successful academically when they were first encouraged to develop concepts and literacy in their native language (Krashen \& Biber, 1988; Troike, 1979; Willig, 1985). Research also supported the theory that bilingual students transferred literacy skills to a second language (Barnitz, 1985; Cohen, 1987; Garcia \& Padilla, 1985; Lambert \& Tucker, 1972; Vygotsky, 1962; Wong, 1992).

However, research on the effectiveness of using English as the sole medium of-instruction in Hong Kong English classrooms from the student perspective is rather limited (He, 2007). Therefore, this paper is intended to fill this research gap and enrich this area of language and educational research.

\section{RESEARCH QUESTIONS}

This study endeavours to examine the effectiveness of using English as the sole medium of instruction in Hong Kong English classrooms by analysing the responses to two research questions:

- RQ1: How do students of the two classes respond to the implemented classroom language policy?

- RQ2: How do student English-class language preferences relate to their attaining a better English proficiency?

In answering these two questions, educators will gain new insights that will help to determine the best way to implement classroom-language policy. Likewise, light can also be shed on effective English teaching and learning in different ESL contexts.

\section{Methodology}

\subsection{Participants}

In this study, two senior secondary ESL classes in Hong Kong (Class E and Class P) were chosen as project classes. The student profiles of both classes were essentially homogeneous, and both classes were facing public examinations the following year. Students were admitted 
to the school with English grade results of either D or E (A is highest, F is a failed grade). The numbers of students in the two classes were 24 (Class E) and 25 (Class P), yielding a total of 49 participants.

\subsection{Classroom language policy implemented}

Action research was conducted in order to investigate the effectiveness of using English as the sole medium of instruction in ESL classrooms. Both classes were taught by the same researcher, who also enacted the English-only classroom language policy in both classes; only Class $\mathrm{P}$ would be penalised if any student spoke anything other than English, whereas Class E would receive merely a verbal reminder that English was the sole language permitted, thus tacitly allowing some minimal mother tongue usage. This research design aimed to compare student preferences on medium of instruction and how their preferences related to English proficiency gained over time. This entire action research transpired over 11 months.

\subsection{Instrumentation}

\subsubsection{Questionnaire}

Seven months into the ESL course, students received a questionnaire (see Appendix 1) requesting their responses on the use of English as the medium of instruction. Questionnaire items were all constructed in positive statements so as to avoid what Cohen, Manion, \& Morrison (2000) \& Oppenheim (1992) pointed out the negative questions were ambiguous and hard to draw spontaneous responses. Answers could range from 6 for "Strongly Agree" to 1 for "Strongly Disagree": 5 for Agree, 4 for Tend to Agree, 3 for Tend to Disagree and 2 for Disagree. A six-point scale was used to lower respondents' tendency to choose the neutral response. Simple English was used, as all students were familiar with that language level.

\subsubsection{English Proficiency Test}

A final English proficiency examination was administered to all students in the same form. This English exam consisted of four papers: (1) Writing, (2) Reading, (3) Listening and (4) Speaking. All papers carried an equivalent weighting, and a maximum mark of $100 \%$. All tests were randomly double-marked by two senior teachers who were also teaching the same form to ensure the reliability of the assessment, except Paper 2 (Reading) because as an itemised multiple-choice test, moderation is not required from a second marker.

\subsubsection{Interview}

Ten students were randomly drawn from each of the two classes. There were five female students and five male students with differing English proficiencies. Student interviews were conducted in counselling rooms in their home schools, a non-threatening environment which could help respondents better express their English-learning opinions and experiences without concern. Further to this point, the interviews were conducted by an impartial researcher who had no influence on the study. The researcher first thanked the students, then stated the 
purpose of the interviews and how they would be conducted. Students were interviewed in their native Cantonese, and assured that their identities would remain confidential. Semistructured and open-ended questions were asked to elicit the best student responses to particular situations (see Appendix 2).

\subsubsection{Observation and journal keeping}

As the English teacher was also the researcher, she was able to immediately log classroom observations in a journal for future reference. A random of 5 lessons for each class were also videotaped.

\subsection{Data analysis}

Mean scores and standard deviations were calculated to examine student preferences for English as the sole medium of instruction in English classes. Inferential statistics, an independent sample $t$-test in an Analysis of Variance (ANOVA), was also used to determine if there was any significant difference between the two policies enacted in the two classes. The groups were considered independent if a member of one group/class could not possibly be in the other group/class. The significance level was set at $p<0.05$. Since multiple comparisons were to be made within the same data-set, the probability of observing a sizeable difference in one of the comparisons increased with the number of comparisons made. To control Type I error, the significance level after Bonferroni adjustments was set to $p<0.001$. This adjustment controlled very tightly for false positives.

\subsection{Reliability and internal consistency of questionnaire}

A reliability test on the 11-item questionnaire was run to determine the internal consistency within the questions. Reliability coefficient (Cronbach alphas) was high, with alpha values of 0.731 and 0.739 , indicating that the internal consistency of the 11 items in the questionnaire was high.

\subsection{Reliability of English test scale score}

Regarding reliability of the English tests, the test-retest method was adopted to see if the first set of scores were correlated with the second set of scores. That is, the same test papers were given to students before intervention and re-used after intervention. The correlations found were 0.78 (Listening) and 0.68 (Reading). The internal consistency using Cronbach alpha results were 0.70 (Listening) and 0.68 (Reading).

The reliability of the speaking and writing results could not be reported in the same manner because they were not item-based tests. To ensure the reliability of the tests, speaking and writing were assessed by two senior teachers according to detailed descriptive criteria. Sample writing scripts and oral assessment tapes were randomly double-marked. Analysis of the marks given by paired markers produced correlations of 0.82 (Writing) and 0.76 (Speaking). 


\section{Results}

RQ1: How do students of the two classes respond to the implemented classroom language policy?

Table 1. Summary statistics and reliability estimation for the questionnaire (N=49).

\begin{tabular}{|c|c|c|c|c|}
\hline Variables & Subjects & Mean & $\begin{array}{l}\text { Standard } \\
\text { Deviation } \\
\end{array}$ & $\begin{array}{l}\text { Cronbach Alpha } \\
\text { (reliability) }\end{array}$ \\
\hline \multirow{2}{*}{$\begin{array}{l}\text { I like it when my English teacher } \\
\text { only uses English as he medium of } \\
\text { instruction. }\end{array}$} & $25(\mathrm{P})$ & 4.76 & 0.822 & 0.786 \\
\hline & $24(\mathrm{E})$ & 4.72 & 0.924 & 0.820 \\
\hline \multirow[t]{2}{*}{$\begin{array}{l}\text { Only using English in the classroom } \\
\text { can improve my English standard. }\end{array}$} & $25(\mathrm{P})$ & 5.24 & 0.722 & 0.741 \\
\hline & $24(\mathrm{E})$ & 4.58 & 0.924 & 0.722 \\
\hline \multirow[t]{2}{*}{$\begin{array}{l}\text { My confidence in speaking English } \\
\text { has been raised. }\end{array}$} & & & & 0.812 \\
\hline & $25(\mathrm{P})$ & 5.58 & $\begin{array}{l}0.822 \\
0.924\end{array}$ & 0.820 \\
\hline \multirow{2}{*}{$\begin{array}{l}\text { Given the choice, I prefer using } \\
\text { English-only in English classes } \\
\text { instead of mixing it with Cantonese. }\end{array}$} & $25(\mathrm{P})$ & 5.24 & 0.822 & 0.689 \\
\hline & $24(\mathrm{E})$ & 4.68 & 0.924 & 0.702 \\
\hline \multirow{2}{*}{$\begin{array}{l}\text { English teachers are good examples } \\
\text { if they only use English in English } \\
\text { class. }\end{array}$} & $25(\mathrm{P})$ & 5.76 & 0.822 & 0.688 \\
\hline & $24(\mathrm{E})$ & 5.68 & 0.924 & 0.710 \\
\hline \multirow{2}{*}{$\begin{array}{l}\text { Enforcing the "No Cantonese in } \\
\text { English Class" policy does not alarm } \\
\text { me. }\end{array}$} & $25(\mathrm{P})$ & 4.80 & 0.822 & 0.820 \\
\hline & $24(\mathrm{E})$ & 5.20 & 0.924 & 0.678 \\
\hline \multirow[t]{2}{*}{$\begin{array}{l}\text { It is fun to listen to my friends } \\
\text { speaking English in class. }\end{array}$} & $25(\mathrm{P})$ & 5.40 & 0.822 & 0.674 \\
\hline & $24(\mathrm{E})$ & 4.68 & 0.924 & 0.736 \\
\hline \multirow[t]{2}{*}{$\begin{array}{l}\text { I will not be upset if my friends also } \\
\text { speak English in class. }\end{array}$} & $\underline{25(\mathrm{P})}$ & 5.24 & 0.822 & 0.670 \\
\hline & $24(\mathrm{E})$ & 5.50 & 0.924 & 0.702 \\
\hline
\end{tabular}


Table 1. Summary statistics and reliability estimation for the questionnaire $(N=49)$. (Cont.).

\begin{tabular}{lllll}
\hline $\begin{array}{l}\text { If my friends don't speak English, I } \\
\text { won't either. }\end{array}$ & & & 0.822 & 0.684 \\
\cline { 2 - 5 } & $25(\mathrm{P})$ & 5.34 & 0.924 & 0.742 \\
\hline $\begin{array}{l}\text { If my English teacher uses } \\
\begin{array}{l}\text { Cantonese to teach English, I will be } \\
\text { annoyed. }\end{array}\end{array}$ & 5.40 & & 0.800 \\
\cline { 2 - 5 } & $25(\mathrm{P})$ & 5.82 & 0.822 & 0.768 \\
\hline $\begin{array}{l}\text { As these are English lessons, we } \\
\text { should use English as much as } \\
\text { possible. }\end{array}$ & 5.62 & 0.924 & 0.674 \\
& $25(\mathrm{P})$ & 5.68 & 0.822 & \\
\hline Average & $24(\mathrm{E})$ & 4.88 & 0.924 & 0.730 \\
\hline & $25(\mathrm{P})$ & 5.33 & 0.822 & 0.731 \\
\hline
\end{tabular}

According to Table 1, the 5P class shows a stronger preference for English as the only medium of instruction in English classes. This can be explained by the fact that students enjoyed the English-rich environment created by the teacher. As native Cantonese speakers, students found an English-only environment more challenging, having to carefully avoid the 'slip-of-tongue' phenomenon that is so prevalent in non-native English speakers.

Students of Class P did their utmost to avoid slips-of-tongue. One student observed that:

"I enjoy the fun and laughter when my fellow students did not even aware of one or two words of Cantonese were slipped through their tongues. Their carelessness reminded me not to follow their steps." (KC, 45)

As for Class E, students did not enjoy the same experience as 5P did. It is very possible that $5 \mathrm{E}$ would have the same feeling if the same policy had been strictly enforced in their class. However, one student responded:

"I didn't use full English to communicate in English lessons with friends because I didn't want other classmates commented me and said I showed off my English." $(\mathrm{GW}, 62)$.

This response shows peer pressure as a main obstacle to in-class English usage. It is, therefore, the responsibility of the teachers to create an 'English only' environment and strictly enforce the classroom language policy to achieve optimum results — and perhaps even help students see learning English more like a game to be won.

The above findings can be supported by the analysed lesson observation data, the amount of English spoken with the teacher in each class were also different and it is evident that student of Class P spoke more substantial amount of English in class. 
Table 2. Number of English Utterances Spoken with the Teacher in Class $(N=49)$.

\begin{tabular}{|c|c|c|c|}
\hline Lessons & Subjects & English Utterances & Cantonese Utterances \\
\hline \multirow{2}{*}{1} & $25(\mathrm{P})$ & 38 & 2 \\
\hline & 21 & 16 & \\
\hline \multirow{2}{*}{2} & $25(\mathrm{P})$ & 46 & 0 \\
\hline & 22 & 12 & \\
\hline \multirow{2}{*}{3} & $25(\mathrm{P})$ & 47 & 1 \\
\hline & 28 & 10 & \\
\hline \multirow{2}{*}{4} & $25(\mathrm{P})$ & 26 & 0 \\
\hline & 19 & 13 & \\
\hline
\end{tabular}

RQ2: How do student English-class language preferences relate to their attaining a better English proficiency?

Table 3. Mean of English proficiency $(N=49)$.

\begin{tabular}{|c|c|c|c|c|}
\hline Variables & Subjects & Mean & $t$ value & $\begin{array}{l}\text { Correlation } \\
\text { Significance }\end{array}$ \\
\hline \multirow[b]{2}{*}{ Reading } & $25(\mathrm{P})$ & 70.4 & 3.462 & $p<0.052$ (NS) \\
\hline & 68.8 & & & \\
\hline \multirow[b]{2}{*}{ Writing } & $25(\mathrm{P})$ & 67.8 & 2.865 & $p<0.084$ (NS) \\
\hline & 65.4 & & & \\
\hline \multirow[b]{2}{*}{ Speaking } & $25(\mathrm{P})$ & 72.8 & 2.786 & $p<0.001$ \\
\hline & 66.4 & & & \\
\hline \multirow[b]{2}{*}{ Listening } & $25(\mathrm{P})$ & 78.8 & 3.124 & $p<0.001$ \\
\hline & 70.6 & & & \\
\hline \multirow[b]{2}{*}{ Average } & $25(\mathrm{P})$ & 71.8 & 3.059 & $p<0.001$ \\
\hline & 68.4 & & & \\
\hline
\end{tabular}

Table 2 shows that Class P's English skills are consistently higher than Class E's, and that Class P has a stronger positive correlation with better English results. Class P is also better at speaking and listening. These results echoed the findings of the questionnaire (Items 2 and 3 ). Class P students themselves felt that their English quality had improved due to the strict classroom language policy. Their confidence in speaking English was also enhanced as a result.

It is also true that Class $\mathrm{P}$ students were more confident in English, as their practical heuristic or 'trial and error' learning method had given them more opportunities to correct and learn from their mistakes. Even better, the more English they spoke in class, the more confident they became with it. According to the teacher's classroom observations, Class P was much more active than Class E. Her journal states: 
"Students are so talkative that sometimes I have to quiet them down. You don't get too many chances to see English teachers quiet down students who are speaking English in class. Every time I say things that arouse their interest, they just talk on and on. This is quite rare...you can tell that they are really enjoying the class, which I am glad to see." (Journal, 21).

Students from Class P also generally responded similarly to this individual:

"I did not have a choice in English classes. If I want to talk, I must speak in English. Our teacher does not tolerate a single word of Cantonese at all. I have to speak English, my friends have to speak English. If everyone speaks the same language, you won't feel embarrassed because there is nothing called 'peer pressure' here." (SS, 31).

This quotation reveals that 'face' was no longer a significant issue in L2 learning. Once this psychological barrier was removed, students felt free to try language hypotheses and strive harder to improve their proficiency.

This positive Class $\mathrm{P}$ atmosphere, along with increased exposure to the English-only environment, enhanced the students' confidence in using English. The more they enjoyed and were exposed to a strict English environment, the better English results they achieved.

From the above observations, it was clear that Class P students were generally keen to use only English in class. However, not all insights are easily apparent in statistical results many Class E students, although somewhat favouring 'English-only' English lessons, actually did not strongly prefer that this policy be implemented, and believed that some leeway for the use of Cantonese could in fact facilitate better learning.

This inclination was expressed during interviews. One respondent pointed out that:

"First-language sometimes helps better understanding, especially teacher needed to clarify some complicated concepts. It is also 'time-consuming' to using English to explain a simple vocabulary item, which in fact can be done within a second of Cantonese is used...I believe Cantonese can be saved as 'emergency' used." (FT, 28)

The view of these students supports the theory that bilingual students transfer literacy skills to a second language (Barnitz, 1985; Padilla, 1990; Vygotsky, 1962).

\section{Discussions \& IMPLiCATIONS}

The design of this study aims to evaluate the English-only medium of instruction policy for English lessons, and the effects of enforcement. Evidence indicates that students should be exposed to as much English as possible in English lessons, as English proficiency is the main objective of English teaching and learning. More importantly, students will become more comfortable in an English-rich communication forum, helping them to perceive English less as a dry 'theoretical' subject and more as a vibrant, living means of dialogue. 
This study found that students who were strictly required to use English in class were more active in class participation. Exposure to English was also increased because students literally have no other options. However, if students are allowed their choice of English or Cantonese during English lessons, they will naturally choose their native tongue due to peer pressure, as well as 'face'.

In addition, it has now been proven that enforcement of a strict English-only policy with English students has a great positive impact on learning. Although starting out equally, the two classes in this study developed their English proficiency at differing rates. Class P students spoke English more frequently and freely in English classes because of strict English-only policy enforcement, while students in Class E generally chose to speak Cantonese among themselves (though not with their teacher); consequently this limited their English exposure, their practice, and quite obviously their confidence, and thus their English proficiency grew less than that of Class P. This correlation clearly indicates how crucial the teacher's role is in creating a classroom language atmosphere that is conducive to learning.

\section{Limitations OF STUDY}

There were some limitations with respect to the methodology of this study which could potentially have affected the accuracy of results.

First, the control group and the experimental group were not randomly chosen because the researcher could not get access to other classes to conduct research. Convenient sampling was therefore the only sampling method adopted for this study.

Second, the participants of this study were of differing language proficiencies. Statistically, the two groups could only be measured by their entrance grade to determine the level of homogeneity. Plus there were no pre-tests nor post-tests conducted during the study. Therefore, the results might not reflect possible improvement within the experimental group due to a strict policy only or lack thereof, that is, there may have already been other differences contributing to the learning effect.

Third, bias from the researcher might also have affected the validity of the study, as the researcher was also the teacher for the two groups/classes. Triangulation research methods were therefore adopted so as to minimise the researcher's bias.

\section{Conclusions}

The issue of whether English should be the sole medium of instruction in teaching English has long been a controversy. This study found that students are indeed generally in favour of using English exclusively in this setting, and their preference is positively related to their own English proficiency. Such classroom language policy provided these students with the chance to use English as the sole means of communication, rather than merely conducting an academic exercise. If teachers allow native languages to be used in English classrooms, student opportunities to learn English are lessened. In a rather monolingual society, maximising students' chances and exposure to English should be one of the prime responsibilities of an English teacher. 
Allowing bilingualism in English classroom will generally only deprive students of an excellent opportunity to use and learn English.

In conclusion, it is the individual English teacher who plays the deciding role in what kind of English-learning atmosphere will be established. How English-rich the teaching environment becomes greatly depends on how determined each English teacher is in maximising the English exposure of students through policy and its enforcement.

\section{REFERENCES}

Barnitz, J. G. (1985). Reading Development of Nonnative Speakers of English. Orlando: Harcourt Brace Jovanovich, Inc.

Bruner, J. (1984). Language, mind and reading. In H. Goelman, A. Oberg, \& F. Smith (Eds.) Awakening toLiteracy. Exeter, NH: Heineman.

Chan, A. (1996). A Study of English Medium Instruction in Secondary 1 in Hong Kong Schools. Hong Kong: Hong Kong Institute of Education.

Chan, A. (1997). English Medium Instruction in Secondary 1 and 2 in Hong Kong Schools: an evaluation of policy implementation. Hong Kong: Hong Kong Institute of Education.

Chan, S. H. \& Tan, H. (2006). English for Mathematics and Science: Current Malaysian Languagein-Education Policies and Practices. Language and Education, 20 (4), pp. 306-321.

Cohen, L., Manion, L. \& Morrison, K. (2000). Research Methods in Education. London \& New York: RoutledgeFalmer.

Ferguson, G. (2006). Language Planning and Education. Edinburgh University Press.

He, R. (2007). Student Performance in Chinese Medium-of-instruction (CMI) and English Mediumof-instruction (EMI) Schools: what we learned from the PISA study. The Chinese University of Hong Kong.

Johnson, R. K. (1993). Using English as the medium of instruction. Hong Kong: Longman.

Krashen, S. \& Biber, D. (1988). On Course: Bilingual Education's Success in California. Sacramento, CA: California Association for Bilingual Education.

Lai, M. L. (2002). Language Attitudes of the First Post-colonial Generation in Hong Kong Secondary Schools: issues in gender, medium of instruction, social class and cultural identity. Unpublished Thesis (Ed.D.) of University of Durham.

Mahwah, N. J. (2004). Medium of Instruction Policies: which agenda? whose agenda? Lawrence Erlbaum Associates Publishers.

Oppenheim, A. N. (1992). Questionnaire Design, Interviewing and Attitude Measurement. London: Pinter Publishers Ltd.

Padilla, A. M. (1990). Bilingual Education: issues and strategies. Newbury Park: Sage Publications.

Poon, A. Y. K. (2000). Medium of Instruction in Hong Kong: policy and practice. University Press of America.

Smith, F. (1983). Essays into Literacy. London: Heineman Educational Books.

Troike, R.C. (1979). Research evidence for the effectiveness of bilingual education. NABE Journal, 3, 13-24.

Vygotsky, L.S. (1962). Thought and Language. Cambridge, MA: MIT Press.

Weaver, C. (1988). Reading Process and Practice: From sociopsycholinguistics to whole language. Portsmouth, NH: Heineman. 
Wells, G. (1986). The Meaning Makers: Children learning language and using language to learn. Portsmouth, NH: Heineman.

Willig, A.C. (1985). A meta-analysis of selected studies on the effectiveness of bilingual education. Review of Educational Research, 55 (3), 269, 317.

Wong, K. (1992). Medium of Instruction Grouping Assessment (MIGA): final report. Hong Kong: Hongkong Bank Foundation. 


\section{Appendix 1: Questionnaire}

\section{English Teaching Questionnaire}

State your preference by circling the appropriate number.

\begin{tabular}{|c|c|c|c|c|c|c|c|}
\hline & & \begin{tabular}{|l} 
Strongly \\
Disagree
\end{tabular} & Disagree & \begin{tabular}{|l|} 
Tend to \\
Disagree
\end{tabular} & $\begin{array}{l}\text { Tend to } \\
\text { Agree }\end{array}$ & Agree & $\begin{array}{l}\text { Strongly } \\
\text { Agree }\end{array}$ \\
\hline 1 & $\begin{array}{l}\text { I like it when my English teacher only uses } \\
\text { English as the medium of instruction. }\end{array}$ & 1 & 2 & 3 & 4 & 5 & 6 \\
\hline 2 & $\begin{array}{l}\text { Speaking English-only in the classroom } \\
\text { can improve my English standard. }\end{array}$ & 1 & 2 & 3 & 4 & 5 & 6 \\
\hline 3 & $\begin{array}{l}\text { My confidence in speaking English has } \\
\text { been raised. }\end{array}$ & 1 & 2 & 3 & 4 & 5 & 6 \\
\hline 4 & $\begin{array}{l}\text { Given the choice, I prefer using English- } \\
\text { only in English classes instead of mixing it } \\
\text { with Cantonese. }\end{array}$ & 1 & 2 & 3 & 4 & 5 & 6 \\
\hline 5 & $\begin{array}{l}\text { English teachers are good examples if they } \\
\text { only use English in English class. }\end{array}$ & 1 & 2 & 3 & 4 & 5 & 6 \\
\hline 6 & $\begin{array}{l}\text { Enforcing the "No Cantonese in English } \\
\text { Lessons" policy does not alarm me. }\end{array}$ & 1 & 2 & 3 & 4 & 5 & 6 \\
\hline 7 & $\begin{array}{l}\text { It is fun to listen to my friends speaking } \\
\text { English in class. }\end{array}$ & 1 & 2 & 3 & 4 & 5 & 6 \\
\hline 8 & $\begin{array}{l}\text { I will not be upset if my friends also speak } \\
\text { English in class. }\end{array}$ & 1 & 2 & 3 & 4 & 5 & 6 \\
\hline 9 & $\begin{array}{l}\text { If my friends don't speak English, I won't } \\
\text { either. }\end{array}$ & 1 & 2 & 3 & 4 & 5 & 6 \\
\hline 10 & $\begin{array}{l}\text { If my English teacher uses Cantonese to } \\
\text { teach English, I will be annoyed. }\end{array}$ & 1 & 2 & 3 & 4 & 5 & 6 \\
\hline
\end{tabular}

\section{Appendix 2: Interview questions}

1. In your English lessons this year, which language did your English teacher normally use?

2. Would you prefer that your teacher use only English in English lessons? Or mainly English and sometime supplement with Cantonese?

3. Did you have any difficulties understanding your English teacher?

4. Do you only use English in your English lessons? Would there be any circumstances where you use a language other than English? Why? Why not?

5. To what extent do you think that using English as the only medium of instruction is helpful to the growth of your English skills? 